\title{
PERENCANAAN ASUHAN KEPERAWATAN SEBAGAI PEDOMAN DALAM MENENTUKAN INTERVENSI KEPERAWATAN
}

\author{
Elisa Claudia Simanjuntak / 181101114 \\ elclaudia02@gmail.com
}

\begin{abstract}
ABSTRAK
Latar Belakang : Peningkatan taraf kesehatan pasien dipengaruhi oleh intervensi keperawatan yang ditentukan oleh perawat.

Tujuan : Tujuan penulisan kajian ini adalah untuk mengetahui perencanaan asuhan keperawatan yang menjadi pedoman dalam melakukan atau menetapkan intervensi keperawatan.

Metode : Metode yang digunakan dalam kajian ini adalah literature review, yaitu dengan cara menganalisis, mengeksplorasi serta mengkaji bebas jurnal dan buku teks yang membahas tentang perencanaan asuhan keperawatan.

Hasil : Hasil kajian menunjukkan bahwa dengan membuat intervensi, perawat akan membantu klien untuk mencapai kriteria hasil, mencapai tujuan dan menyelesaikan masalah kesehatannya.

Pembahasan : Tahap ketiga dari proses keperawatan adalah perencanaan. Perencanaan dilakukan untuk mencapai tujuan dalam menentukan intervensi keperawatan. Perencanaan asuhan keperawatan dilakukan dalam tiga fase, yaitu menentukan prioritas masalah (diagnosa), merumuskan tujuan dan kriteria hasil, dan membuat intervensi keperawatan.

Kata Kunci : Perencanaan, Asuhan Keperawatan, Intervensi Keperawatan.
\end{abstract}




\section{Latar Belakang}

Rumah sakit merupakan sarana penyedia layanan kesehatan bagi pasien. Di rumah sakit, pasien berhak memperoleh pelayanan prima. Pelayanan prima adalah kepedulian kepada pasien dengan memberikan layanan terbaik untuk memfasilitasi kemudahan pemenuhan kebutuhan dan mewujudkan kepuasannya (Barata, 2003).

Di rumah sakit, perawat memiliki peran besar terhadap kelangsungan perawatan pasien. Perawat bertugas memberikan asuhan keperawatan yang berkualitas. Pemberian asuhan keperawatan saat ini berfokus kepada cara menyembuhkan penyakit maupun meningkatkan taraf kesehatan pasien. Peningkatan taraf kesehatan pasien dipengaruhi oleh intervensi keperawatan yang ditentukan oleh perawat. Untuk dapat menentukan intervensi keperawatan yang tepat bagi pasien, perlu dilakukan pengkajian terhadap data-data yang diperoleh melalui proses keperawatan.

\section{Tujuan}

Pengkajian ini dilakukan untuk
mengetahui perencanan asuhan keperawatan yang menjadi pedoman dalam melakukan atau menetapkan intervensi keperawatan.

\section{Metode}

Metode yang digunakan dalam kajian ini adalah literature review, yaitu dengan cara menganalisis, mengeksplorasi serta mengkaji bebas jurnal dan buku teks yang membahas tentang perencanaan asuhan keperawatan. Referensi berupa jurnal dan buku teks yang digunakan adalah sebanyak 14. Jurnal yang digunakan sebagai referensi dalam tulisan ini diterbitkan dalam kurun waktu 10 tahun terakhir.

\section{Hasil}

Perencanaan dilakukan untuk mencapai tujuan dalam menentukan intervensi keperawatan. Dengan membuat intervensi, perawat akan membantu klien untuk mencapai kriteria hasil, mencapai tujuan dan menyelesaikan masalah.

\section{Pembahasan}

Tahap ketiga dari proses keperawatan adalah perencanaan. Selama tahap ini, diagnosa 
diprioritaskan, tujuan dan kriteria hasil disusun, intervensi diidentifikasi, dan sebuah rencana asuhan dikembangkan. Perencanaan dilakukan untuk mencapai tujuan dalam menentukan intervensi keperawatan. Dalam melakukan perencanaan, perawat harus berkolaborasi dengan pasien dan keluarganya serta tenaga kesehatan lain.

Perencanaan asuhan keperawatan dilakukan dalam tiga fase, yaitu menentukan prioritas masalah (diagnosa), merumuskan tujuan dan kriteria hasil, dan membuat intervensi keperawatan.

1. Menentukan prioritas masalah (diagnosa)

Fase ini merupakan proses dimana terjadi pengambilan keputusan. Untuk dapat memprioritaskan masalah, perawat harus mampu berpikir kritis dalam mengidentifikasi masalah yang paling penting dan mengambil keputusan yang tepat. Hierarki tentang kebutuhan dapat digunakan perawat untuk merencanakan kebutuhan klien. Menurut Maslow, ada lima tingkat kebutuhan pasien yang diurutkan sebagai berikut: kebutuhan fisiologis, kebutuhan keamanan dan keselamatan, kebutuhan mencintai dan dicintai, kebutuhan harga diri, dan kebutuhan aktualisasi diri. Perawat dapat menggunakan prioritas untuk menentukan intervensi.

2. Merumuskan tujuan dan kriteria hasil Tujuan dan kriteria hasil yang diperkirakan adalah pernyataan spesifik tentang perilaku atau respon klien yang perawat antisipasi dari asuhan keperawatan. Tujuan dan kriteria hasil dapat memberikan arahan untuk intervensi keperawatan dan menentukan keefektifan intervensi.

3. Membuat intervensi keperawatan

Dengan membuat intervensi, perawat akan membantu klien untuk mencapai kriteria hasil, mencapai tujuan dan menyelesaikan masalah (Rubenfeld dan Scheffer, 1999). Terdapat tiga kategori intervensi, yaitu intervensi perawat, intervensi dokter, dan intervensi kolaboratif. Pemilihan katergori intervensi didasarkkan pada kebutuhan klien.

\section{Penutup}

Perencanaan merupakan tahap ketiga dalam proses keperawatan. Perencanaan dilakukan untuk mencapai tujuan dalam menentukan intervensi keperawatan. Dalam melakukan perencanaan, perawat harus berkolaborasi dengan pasien dan keluarganya serta tenaga kesehatan lain. 


\section{Referensi}

Ali, H. Z. (2010). Dasar-dasar

Perencanaan Keperawatan. Jakarta:

Trans Info Media.

Astar, F. dkk. (2018). Pengaruh

Pelayanan Asuhan Keperawatan

Terhadap Kepuasan Pasien di

Puskesmas Takalala Kabupaten

Soppeng. Journal of Management. 1(2): 33-57.

Deswani. (2009). Proses Keperawatan dan Berpikir Kritis. Jakarta: Salemba Medika.

Haryanto. (2008). Konsep Dasar Keperawatan dengan Pemetaan Konsep (Concept Mapping). Jakarta: Salemba Medika.

Hastuti, W. \& Widiyaningsih. (2017). Aplikasi Concept Mapping Dalam Pemberian Asuhan Keperawatan di Stase Maternitas. Jurnal Keperawatan dan Pemikiran Ilmiah. 3 (3): 19-26.

Lismidar, H. dkk. (1990). Proses Keperawatan. Jakarta: UI Press.
Maryam, Siti, dkk. (2006). Buku Ajar Berpikir Kritis dalam Proses Keperawatan. Jakarta: EGC.

Potter \& Perry. (2005). Buku Ajar Fundamental Keperawatan: Konsep, Proses, dan Praktik Edisi 4. Jakarta: EGC.

Simamora, R.H. (2009). Dokumentasi Proses Keperawatan. Jember: Jember University Press.

Simamora, R.H. (2010). Komunikasi dalam Keperawatan. Jember: Jember University Press.

Simamora, R. H. (2008). Peran Manajer dalam Pembinaan Etika Perawat Pelaksana dalam Peningkatan Kualitas Pelayanan Asuhan Keperawatan. Jurnal IKESMA. 4(2).

Tarwoto \& Wartonah. (2012). Kebutuhan Dasar Manusia dan Proses Keperawatan. Jakarta: Salemba Medika.

Vaughans, Bennita W. (2013). Keperawatan Dasar. Yogyakarta: Rapha Publishing. 